Check for updates

Cite this: RSC Adv., 2018, 8, 4525

Accepted 17th January 2018

DOI: 10.1039/c7ra13403g

rsc.li/rsc-advances

\title{
Fluorine-functionalized ionic liquids with high oxygen solubility $\dagger$
}

\author{
Gijs Vanhoutte, ${ }^{\text {*a }}$ Sandra D. Hojniak, ${ }^{\text {b }}$ Fanny Bardé, ${ }^{c}$ Koen Binnemans (D) *b \\ and Jan Fransaer ${ }^{a}$
}

Eight fluorine-functionalized ionic liquids were synthesized and the oxygen solubility was compared to commercial ionic liquids without the extra fluorinated chain. The concentration of dissolved oxygen increased with the fluorine content of the alkyl chain, which can be attached either to the cation or the anion. This approach maintains the freedom to design an ionic liquid for a specific application, while at the same time the oxygen solubility is increased.

\section{Introduction}

Ionic liquids (ILs) are solvents that consist entirely of ions..$^{1-4}$ They are receiving a lot of attention due to their unique properties, such as low volatility, high (electro)chemical stability, intrinsic electrical conductivity, thermal stability and their highly tuneable properties. Research on gas solubility in ionic liquids is mainly focussed on $\mathrm{CO}_{2}$ due to the high solubility of this gas. ${ }^{5-7}$ Less data are available on the solubility of other gases such as $\mathrm{CO}, \mathrm{N}_{2}, \mathrm{H}_{2}$ and $\mathrm{O}_{2}$ in ionic liquids, because the dissolved gas concentrations are considerably lower. However, this does not mean that such data would be less important. Recently, the dissolution of oxygen in ionic liquids is gaining a lot of interest, thanks to its application in (electro)catalysis and energy storage technologies. ${ }^{8,9}$ In oxidative catalysis, dissolved oxygen is used as oxidant for the oxidation of various reagents, such as alcohols, olefins, nitrotoluene and cysteine. ${ }^{\mathbf{1 0 - 2 0}}$ For the latter reaction, Shan et al. observed that the performance of the catalyst was directly proportional to the solubility of oxygen and that a higher oxygen concentration resulted in higher yields. Ionic liquids with dissolved oxygen have also been used in metal-free catalytic systems for the depolymerization of lignin model compounds and lignin, ${ }^{\mathbf{2 1 , 2 2}}$ or as solvent for transition-metal catalyzed oxidation of lignin model compounds. ${ }^{23}$

\footnotetext{
${ }^{a}$ Department of Materials Engineering, KU Leuven, Kasteelpark Arenberg 44, B-3001 Leuven, Belgium. E-mail: gijsvanhoutte@gmail.com

${ }^{b}$ Department of Chemistry, KU Leuven, Celestijnenlaan 200F, B-3001 Leuven, Belgium. E-mail: Koen.Binnemans@kuleuven.be; Tel: +32 16321239

${ }^{c}$ Toyota Motor Europe, Advanced Technology 1, Research and Development 3, Technical Center, Hoge Wei 33B, B-1930, Belgium

$\dagger$ Electronic supplementary information (ESI) available: The detailed synthesis and characterization of precursor molecules and ionic liquids is described: ${ }^{1} \mathrm{H}$, ${ }^{13} \mathrm{C},{ }^{19} \mathrm{~F}$ NMR spectra, CHN analysis data, thermogravimetric analysis (TGA), electrochemical procedures and measurements. See DOI: 10.1039/c7ra13403g
}

In the field of energy storage, more specifically for fuel cells and metal-air batteries, there is a lot of interest in the use of ionic liquids as electrolytes. For fuel cells, a high oxygen solubility in ionic liquids is crucial when they are use in (nano) composite electrodes, where it improves the catalytic fourelectron oxygen reduction reaction which is necessary for fuelcell commercialization. ${ }^{24-30}$ On the other hand, rechargeable metal-air batteries use oxygen from the atmosphere as active cathode material and thus present a higher energy density than the conventional lithium-ion battery, which is based on intercalation of ions $\left(\mathrm{Li}^{+}\right)$into a metal oxide host. The mechanism of metal-air batteries with non-aqueous electrolytes is based on a different principle and starts by the reduction of oxygen to the superoxide radical $\mathrm{O}_{2}{ }^{-}$. Subsequently this radical reacts, ideally with the metal ions in solution. Due to the high reactivity of these radicals, special attention has to be paid to the development of appropriate electrolytes that can withstand their attack. Several molecular solvents have been investigated as electrolyte for metal-air batteries, e.g. ethylene carbonate, propylene carbonate, 1,2-dimethoxyethane, diethylene glycol diethyl ether, tetraethylene glycol dimethyl ether, dimethylsulfoxide and acetonitrile. ${ }^{3-41}$ Unfortunately all these solvents have issues such high volatility, flammability, a limited stability in the presence of superoxide radicals or singlet $\mathrm{O}_{2},{ }^{42}$ and a low oxygen solubility. Therefore, ionic liquids are being investigated as alternative electrolytes for metal-air batteries. ${ }^{43-45}$

For biological applications, such as artificial blood, perfluorinated carbons (PFCs) are typically used to increase the oxygen solubility in the solution. ${ }^{4-50}$ The beneficial effect of PFC additives on the performance of metal-air batteries has already been reported in the literature..$^{51-55}$ Nevertheless, the limited miscibility of PFCs in organic solvents remains an issue. One proposed strategy is to make a dispersion of the liquid medium. ${ }^{54}$ However, this approach does not meet the long-term stability requirement of the two-phase liquid/liquid dispersion. 
Another type of organic solvents with a high fluorine content besides the perfluorinated hydrocarbons are some type of ionic liquids (ILs). Typically, fluorine is introduced in the ionic liquid via the anion. Examples include tetrafluoroborate, hexafluorophosphate and bis(trifluoromethylsulfonyl)imide anions. Much less examples are known of ionic liquids with fluorinated alkyl chains in the cation. ${ }^{56-61}$ An alternative approach is via perfluorinated alkyl chains in the anion. ${ }^{62-65}$ However, this approach leads in general to ionic liquids with higher melting points.

In this paper, ionic liquids were functionalized with fluorinated alkyl chains in the cation or anion, making them an inherent part of the electrolyte and not an additive. After the characterization of the physical properties of these fluorinated ionic liquids such as their density, viscosity and thermal stability, electrochemical experiments were conducted to determine the oxygen solubility in those fluorinated ionic liquids, which was shown to be increased with fluorinated chain length.

\section{Experimental}

The detailed synthesis and characterization of precursor molecules and ionic liquids is described in the ESI. $\dagger$ The ionic liquids were characterized by NMR $\left({ }^{1} \mathrm{H},{ }^{13} \mathrm{C},{ }^{19} \mathrm{~F}\right)$, FTIR-ATR, CHN elemental analysis and TGA. In addition, the water content, the viscosity and density of the ionic liquids were measured. All ionic liquids were dried on a vacuum line at $70{ }^{\circ} \mathrm{C}$ for 72 hours and subsequently stored in an argon-filled glove box with oxygen and water concentrations below $1 \mathrm{ppm}$. The water content in the ionic liquids was determined by Karl Fischer coulometry (Mettler-Toledo model DL39) and was always below 20 ppm. Viscosity (dynamic and kinematic) and density of the ionic liquids were measured by an Anton Paar Lovis $2000 \mathrm{M} / \mathrm{ME}$, DMA $4500 \mathrm{M}$ rolling-ball viscometer at $25{ }^{\circ} \mathrm{C}$. Thermogravimetric analysis was performed by using a SDT Q600 (TA Instruments) under a constant argon flow. First the mass was monitored for $60 \mathrm{~min}$ at $25^{\circ} \mathrm{C}$ to evaluate the volatility at room temperature. Subsequently the temperature was increased to $450{ }^{\circ} \mathrm{C}$ at a heating rate of $5{ }^{\circ} \mathrm{C} \mathrm{min}{ }^{-1}$, to evaluate the volatility and thermal stability at higher temperatures. All electrochemical experiments were performed using a threeelectrode set up. The electrochemical cell was filled and closed inside the glove box, followed by gas bubbling outside the glove box. Oxygen gas ( $\geq 99.9995 \%$, Air Liquide, ALPHAGAZ 2) was used for the oxygen dissolution measurements in the ionic liquids. The gas was bubbled through the ionic liquid via a glass tube with a P2 glass filter for 30 minutes. The bubbler was connected to the gas bottle using silicone tubing. To avoid water contamination during bubbling, an extra drying tower (Sigma-Aldrich) was used, filled with activated molecular sieves $3 \AA$ A (beads, 4-8 mesh, Sigma-Aldrich) and placed in between the gas bottle and the electrochemical cell. The molecular sieves were activated overnight at a temperature of $250{ }^{\circ} \mathrm{C}$ under a flow of argon. All glassware used for the experiments was dried overnight in an oven at $120^{\circ} \mathrm{C}$ and transferred into the glove box while still hot. All electrochemical measurements were performed using an Autolab $302 \mathrm{~N}$ bipotentiostat controlled by NOVA 1.11.1 software. Two different working electrodes were used: (1) a gold disk macroelectrode $(\varnothing=0.6 \mathrm{~mm})$ or (2) a gold ultramicroelectrode $(\varnothing=25 \mu \mathrm{m}, \mathrm{CH}$ Instruments Inc.). The real reference electrode was a silver wire ( $\geq 99.98 \%$, Chempur) in a glass tube filled with a dry acetonitrile solution of $0.01 \mathrm{M}$ silver nitrate and $0.1 \mathrm{M}$ tetrabutylammonium perchlorate, which was separated from the electrolyte by a glass frit. The reference tube was assembled at least 30 minutes prior to the electrochemical measurement. A platinum coil was used as counter electrode. The electrochemical cell was placed in an oil bath at $25.0 \pm$ $0.2{ }^{\circ} \mathrm{C}$.

\section{Results and discussion}

\subsection{Synthesis and characterization}

The perfluorinated cations were based on a piperidinium or pyrrolidinium heterocycle or a quaternary ammonium. The perfluorinated anions were based on a carboxylate ion (Fig. 1). For the synthesis of the perfluorinated cations, a general synthetic procedure was followed: (1) synthesis of the fluorinated amino ether, (2) synthesis of the iodide salt and (3) preparation of the final bis(trifluoromethylsulfonyl)imide $\left(\mathrm{Tf}_{2} \mathrm{~N}^{-}\right)$ionic liquid by a metathesis reaction with $\operatorname{LiTf}_{2} \mathrm{~N}$. The first step was based on a modified procedure described by Kim et al. ${ }^{66}$

The physical properties of the fluorinated ionic liquids are reported in Table 1 . It is evident that the density and viscosity of the ionic liquids increased with the fluorine content of the alkyl chain. All six ionic liquids with a fluorinated chain attached to the cation $(\mathbf{1 a}, \mathbf{1 b}, \mathbf{2 a}, \mathbf{2} \mathbf{b}, \mathbf{3 a}, \mathbf{3 b})$ were liquid at room temperature and the dissolved oxygen concentration could be measured as such in the pure ionic liquid. The two ionic liquids $\mathbf{4 a}$ and $\mathbf{4 b}$ with the fluorinated chain attached to the anion, were solid at room temperature and had to be mixed with $N$-butyl- $N$ methylpyrrolidinium bis(trifluoromethylsulfonyl)imide ([BMP] $\left[\mathrm{Tf}_{2} \mathrm{~N}\right]$ ) in a $1: 1$ mass ratio. The resulting ionic liquid mixture was liquid around room temperature and could be used for the electrochemical measurements.

\subsection{Dissolved oxygen concentration}

The dissolved oxygen concentration was obtained via electrochemical measurements and was calculated by combining the Cottrell equation (eqn (1), Fig. 2) on a macroelectrode and the steady-state current on an ultramicroelectrode described by eqn (2) (Fig. 3), for the reduction of oxygen: $\mathrm{O}_{2}+\mathrm{e}^{-} \rightleftharpoons \mathrm{O}_{2}{ }^{--}$. Detailed experimental conditions can be found in the ESI. $\dagger$

$$
\begin{aligned}
& i(t)=\frac{n F A D_{\mathrm{O}_{2}}{ }^{1 / 2} c_{O_{2}}}{\pi^{1 / 2} t^{1 / 2}} \\
& i_{\mathrm{ss}}=4 n F c_{\mathrm{O}_{2}} D_{\mathrm{O}_{2}} r
\end{aligned}
$$

Combining these equations gave values for the dissolved oxygen concentration $c_{\mathrm{O}_{2}}$ and oxygen diffusion coefficient $D_{\mathrm{O}_{2}}$ (Table 2). In Fig. 4, an increase of the oxygen concentration with 

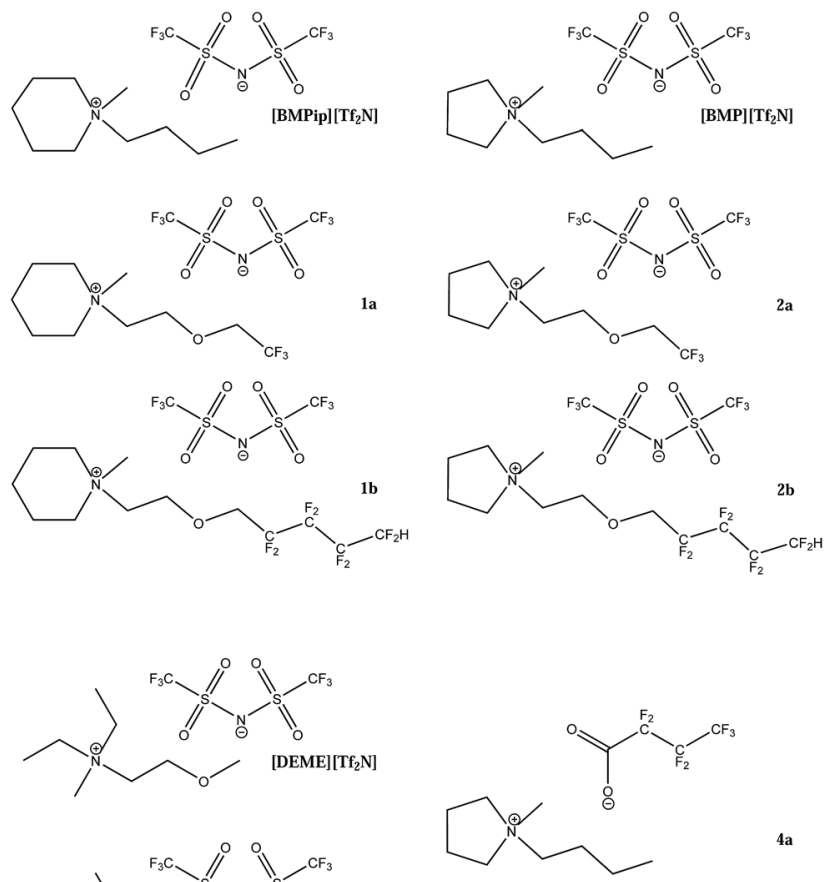

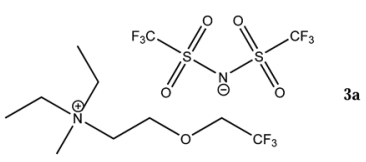

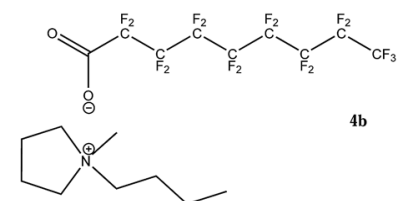

Table 1 Physical properties of the fluorinated ionic liquids used in this work measured at $25^{\circ} \mathrm{C}$

\begin{tabular}{llll}
\hline Ionic liquid & $\begin{array}{l}\text { Density } \\
\left(\mathrm{kg} \mathrm{m}^{-3}\right)\end{array}$ & $\begin{array}{l}\text { Dynamic viscosity } \\
(\mathrm{mPa} \mathrm{s})\end{array}$ & $\begin{array}{l}\text { Decomposition } \\
\text { temperature }^{c}\left({ }^{\circ} \mathrm{C}\right)\end{array}$ \\
\hline$[\mathrm{BMPip}]\left[\mathrm{Tf}_{2} \mathrm{~N}\right]$ & 1379 & 166 & 385 \\
$\mathbf{1 a}$ & 1501 & 228 & 327 \\
$\mathbf{1 b}$ & 1583 & 587 & 341 \\
{$[\mathrm{BMP}]\left[\mathrm{Tf}_{2} \mathrm{~N}\right]$} & 1395 & 82 & 357 \\
$\mathbf{2 a}$ & 1530 & 116 & 329 \\
$\mathbf{2 b}$ & 1609 & 320 & 337 \\
{$[\mathrm{DEME}]\left[\mathrm{Tf}_{2} \mathrm{~N}\right]$} & 1407 & 77 & 325 \\
$3 \mathbf{3 a}$ & 1481 & 144 & 329 \\
$\mathbf{3 b}$ & 1566 & 446 & 302 \\
$\mathbf{4 a}^{a, b}$ & 1295 & 178 & 137 \\
$\mathbf{4 b}^{a}$ & 1442 & 185 & 141
\end{tabular}

$a$ Ionic liquids $\mathbf{4 a}, \mathbf{b}$ were solid at room temperature and were mixed with $[\mathrm{BMP}]\left[\mathrm{Tf}_{2} \mathrm{~N}\right]$ in a $1: 1$ mass ratio. ${ }^{b}$ Measured at $35{ }^{\circ} \mathrm{C} .{ }^{c}$ Dynamic TGA, heating rate $5{ }^{\circ} \mathrm{C} \mathrm{min}^{-1}$. The decomposition temperature is determined as the temperature where $1 \%$ of the initial mass of the ionic liquid is decomposed.

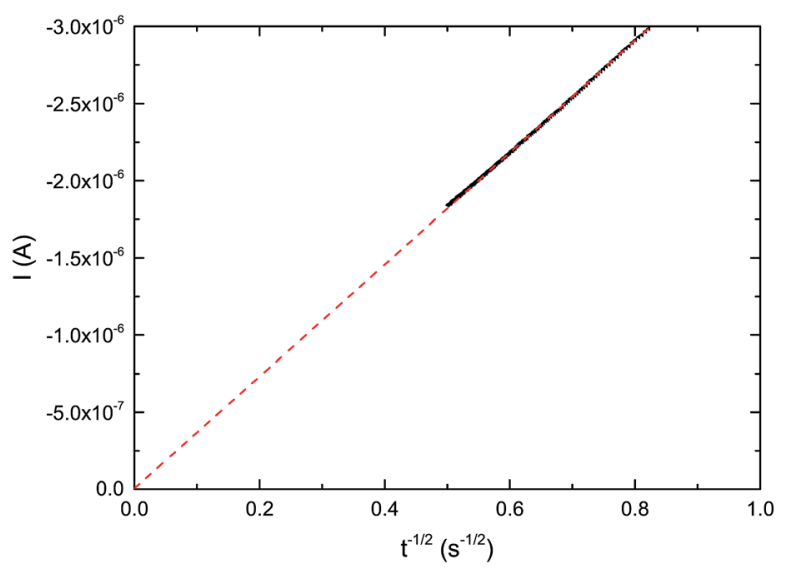

Fig. 2 Linear fit for the determination of the slope the Cottrell equation (eqn (1)). A potentiostatic signal of $-1.65 \mathrm{~V} v \mathrm{vs}$. $\mathrm{Ag}^{+} / \mathrm{Ag}$ was applied, using IL $2 \mathrm{a}$ as electrolyte, a gold macroelectrode $(\phi=0.6 \mathrm{~mm})$ and a platinum counter electrode at room temperature.

chain length, there is a tradeoff between the length of the fluorinated chain to increase the oxygen solubility on one hand and keeping viscosity as low as possible on the other hand. This is also reflected in the decrease of the diffusion coefficient of oxygen with an increasing viscosity and fluorinated chain length (Table 2). Especially for heterogeneous reactions, this is an important parameter to consider. For example, in metal-air batteries the current at the electrode interface is proportional to $c_{\mathrm{O}_{2}} \sqrt{D_{\mathrm{O}_{2}}}$. This value can be seen as the oxygen supply capacity in a stagnant solution and therefore it is a more appropriate parameter to compare the various ionic liquids as electrolytes for metal-air batteries. ${ }^{67}$ In Fig. 5 it can be seen that for the perfluorinated cations, IL $\mathbf{2 a}$ and $\mathbf{3} \mathbf{b}$ perform the best with an oxygen supply capacity that is 1.6 and 1.4 times higher than that of a commercial ionic liquid $[\mathrm{BMP}]\left[\mathrm{Tf}_{2} \mathrm{~N}\right]$ and $[\mathrm{DEME}]\left[\mathrm{Tf}_{2} \mathrm{~N}\right]$, respectively. Note that the oxygen concentration is a more
Since ionic liquids are in general more viscous than molecular solvents and even more so upon increasing the fluorinated 


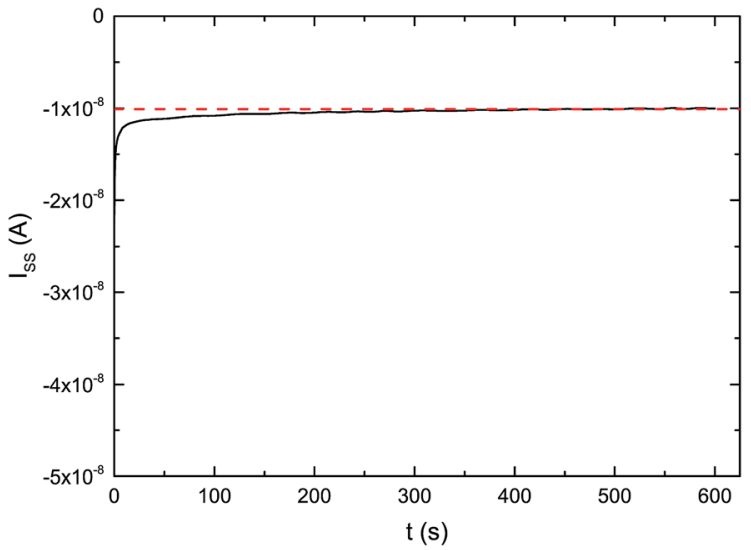

Fig. 3 Steady state current on the ultramicroelectrode $i_{\text {ss }}$ equation (eqn (2)). A potentiostatic signal of $-1.65 \mathrm{~V} v \mathrm{vs}$. $\mathrm{Ag}^{+} / \mathrm{Ag}$ was applied, using IL $2 \mathrm{a}$ as electrolyte, a gold ultramicroelectrode $(\phi=25 \mu \mathrm{m})$ as working electrode and a platinum counter electrode at room temperature.

Table 2 Dissolved oxygen concentration $\left(c_{\mathrm{O}_{2}}\right)$, oxygen diffusion coefficient $\left(D_{\mathrm{O}_{2}}\right)$ measured at $25^{\circ} \mathrm{C}$

\begin{tabular}{lcl}
\hline Ionic liquid & $c_{\mathrm{O}_{2}}\left(\mathrm{~mol} \mathrm{~m}^{-3}\right)$ & $D_{\mathrm{O}_{2}}\left(\times 10^{-10} \mathrm{~m}^{2} \mathrm{~s}^{-1}\right)$ \\
\hline$\left[\right.$ BMPip] $\left[\mathrm{Tf}_{2} \mathrm{~N}\right]$ & 6.3 & 2.2 \\
1a & 16.0 & 0.8 \\
1b & 26.1 & 0.2 \\
{$[\mathrm{BMP}]\left[\mathrm{Tf}_{2} \mathrm{~N}\right]$} & 6.7 & 5.0 \\
$\mathbf{2 a}$ & 26.0 & 0.8 \\
2b & 34.0 & 0.3 \\
{$[\mathrm{DEME}]\left[\mathrm{Tf}_{2} \mathrm{~N}\right]$} & 5.1 & 4.8 \\
3a & 16.0 & 0.7 \\
3b & 29.5 & 0.2 \\
$\mathbf{4 a}$ & 9.6 & 1.2 \\
$\mathbf{4 b}^{a}$ & 19.5 & 1.0
\end{tabular}

${ }^{a}$ Ionic liquids $\mathbf{4 a}, \mathbf{b}$ were solid at room temperature and were mixed with $[\mathrm{BMP}]\left[\mathrm{Tf}_{2} \mathrm{~N}\right]$ in a $1: 1$ mass ratio. ${ }^{b}$ Measured at $35^{\circ} \mathrm{C}$.

important factor than the oxygen diffusion coefficient for the oxygen supply capacity. For IL $\mathbf{4 a}$ and $\mathbf{4 b}$ it can be seen that mixing the fluorinated ionic liquids with $[\mathrm{BMP}]\left[\mathrm{Tf}_{2} \mathrm{~N}\right]$ results in a comparable viscosity and thus a comparable oxygen diffusion coefficient. Doubling the oxygen solubility by increasing the fluorinated chain length, results thus in an oxygen supply capacity that is twice as high. For flow-type systems or homogeneous catalysis, the contribution of the diffusion coefficient becomes even less pronounced for the supply of oxygen. Due to the limited diffusion path length, a high dissolved oxygen concentration will be more important and result in higher reaction rates.

\subsection{Stability of the ionic liquids}

An extra advantage of using fluorinated ionic liquids is their hydrophobicity and low volatility. Therefore, these ionic liquids can be used as solvents in open or half open systems, and even in flow gas systems. The volatility was assessed using

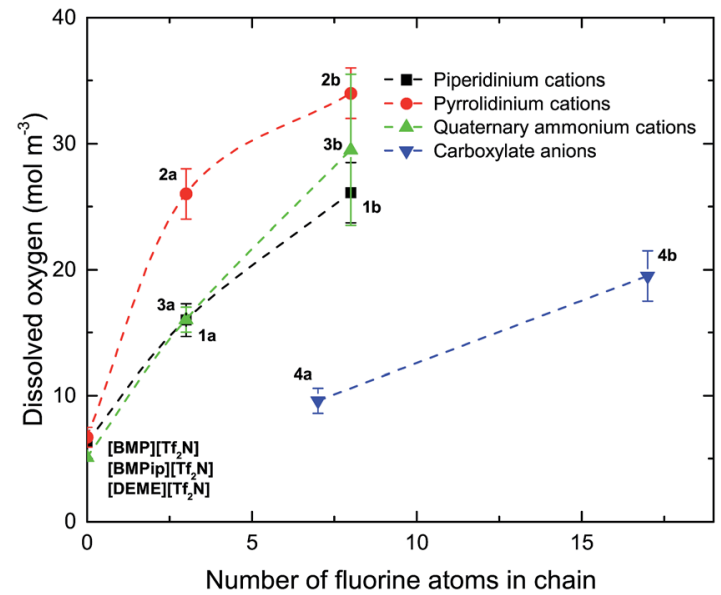

Fig. 4 Influence of fluorine chain length on the dissolved oxygen concentration.

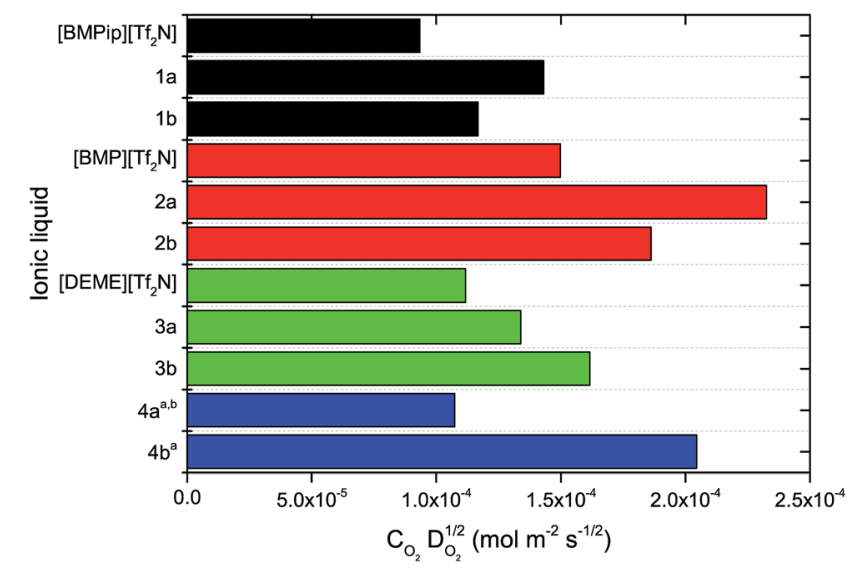

Fig. 5 Oxygen supply capacity of different ionic liquids for the heterogenous oxygen reduction reaction, where the current $I \sim c_{\mathrm{O}_{2}} \sqrt{D_{\mathrm{O}_{2}}}$. ${ }^{\text {a }}$ onic liquids $4 \mathrm{a}, \mathrm{b}$ were solid at room temperature and were mixed with $[\mathrm{BMP}]\left[\mathrm{Tf}_{2} \mathrm{~N}\right]$ in a $1: 1$ mass ratio. ${ }^{\mathrm{b}}$ Measured at $35^{\circ} \mathrm{C}$.

thermogravimetric analysis. The mass of the ionic liquids was monitored for 1 hour at $25{ }^{\circ} \mathrm{C}$ and subsequently, the temperature was increased until the ionic liquid started to decompose. For none of the ionic liquids a mass decrease was observed before the decomposition temperature (Fig. S4-S7†). This is a clear indication that the ionic liquids are non-volatile, not only at room temperature, but also at elevated temperatures. For all ionic liquids with the fluorinated chain attached to the cation, the decomposition temperature was higher than $300{ }^{\circ} \mathrm{C}$. Ionic liquids with a fluorinated carboxylate-anion decomposed at lower temperatures starting at $137^{\circ} \mathrm{C}$ for IL 4 a and $141^{\circ} \mathrm{C}$ for IL $4 \mathbf{b}$ (Table 1). The stability of the ionic liquids against attack of the superoxide radical was assessed by cyclic voltammetry. This is important for applications where dissolved oxygen is reduced to its radical, e.g. metal-air batteries. Although the time required to measure a cyclic voltammogram is relatively short, it provides an insight in the stability and complexation of the superoxide radical in the ionic liquid. All ionic liquids showed 
a reversible oxygen reduction reaction and oxygen evolution reaction at a slow scan rate of $10 \mathrm{mV} \mathrm{s}^{-1}$ during a cyclic voltammogram (Fig. S8-S11†).

\section{Conclusions}

In conclusion, various fluorinated ionic liquids were synthesized to improve the oxygen solubility. Both cations and anions were fluorinated and this resulted in an increase in oxygen solubility. Concentrations up to $34 \mathrm{mM}$ were measured. This is more than five times the concentration of dissolved oxygen in the commercial ionic liquid without a fluorinated alkyl chain. The dissolved oxygen concentration was determined via electrochemical measurements on a macro- and ultramicroelectrode. The stability, low vapor pressure and hydrophobic character of the ionic liquids make them suitable for use in open, half-open or flow systems. Since fluorination of both the cation and anion results in a higher oxygen solubility, there is a freedom to operate and thus, depending on the application, the cation or anion can be used to increase the dissolved oxygen concentrations in the ionic liquid.

\section{Conflicts of interest}

There are no conflicts to declare.

\section{Acknowledgements}

The authors acknowledge financial support of the Battery Research division (M6) at Higashi Fuji Technical Centre in Japan and the IWT Flanders (SBO project 18142 "SoS-Lion") and the KU Leuven (IOF-KP 14/005 "Better Batteries"). We thank Karel Duerinckx for his assistance with the NMR measurements.

\section{References}

1 K. R. Seddon, J. Chem. Technol. Biotechnol., 1997, 68, 351356.

2 T. Welton, Chem. Rev., 1999, 99, 2071-2084.

3 F. Endres, ChemPhysChem, 2002, 3, 144-154.

4 K. Seddon, Nat. Mater., 2003, 2, 363-365.

5 E. D. Bates, R. D. Mayton, I. Ntai and J. H. Davis, J. Am. Chem. Soc., 2002, 124, 926-927.

6 C. Cadena, J. L. Anthony, J. K. Shah, T. I. Morrow, J. F. Brennecke and E. J. Maginn, J. Am. Chem. Soc., 2004, 126, 5300-5308.

7 A. M. Scurto, S. N. V. K. Aki and J. F. Brennecke, J. Am. Chem. Soc., 2002, 124, 10276-10277.

8 D. Betz, P. Altmann, M. Cokoja, W. A. Herrmann and F. E. Kühn, Coord. Chem. Rev., 2011, 255, 1518-1540.

9 M. Armand, F. Endres, D. R. MacFarlane, H. Ohno and B. Scrosati, Nat. Mater., 2009, 8, 621-629.

10 N. Jiang and A. J. Ragauskas, J. Org. Chem., 2007, 72, 70307033.

11 A. Shaabani, E. Farhangi and A. Rahmati, Appl. Catal., A, 2008, 338, 14-19.
12 S. Riaño, D. Fernández and L. Fadini, Catal. Commun., 2008, 9, 1282-1285.

13 S. Kodama, Y. Ueta, J. Yoshida, A. Nomoto, S. Yano, M. Ueshima and A. Ogawa, Dalton Trans., 2009, 9708-9711.

14 H.-Y. Shen, L.-Y. Ying, H.-L. Jiang and Z. M. A. Judeh, Int. J. Mol. Sci., 2007, 8, 505-512.

15 Z. Zhang, L. Hui, L. Yürong and Y. Yühua, Synth. React. Inorg. Met.-Org. Chem., 2009, 39, 144-148.

16 X. Yun, X. Hu, Z. Jin, J. Hu, C. Yan, J. Yao and H. Li, J. Mol. Catal. A: Chem., 2010, 327, 25-31.

17 A. Chrobok, Tetrahedron, 2010, 66, 2940-2943.

18 X. Zhao, A. Kong, C. Shan, P. Wang, X. Zhang and Y. Shan, Catal. Lett., 2009, 131, 526-529.

19 X. Zhao, A. Kong, X. Zhang, C. Shan, H. Ding and Y. Shan, Catal. Lett., 2010, 135, 291-294.

20 M. J. Schultz and M. S. Sigman, Tetrahedron, 2006, 62, 82278241.

21 Y. Yang, H. Fan, J. Song, Q. Meng, H. Zhou, L. Wu, G. Yang and B. Han, Chem. Commun., 2015, 51, 4028-4031.

22 G. Chatel and R. D. Rogers, ACS Sustainable Chem. Eng., 2014, 2, 322-339.

23 J. Zakzeski, A. L. Jongerius and B. M. Weckhuysen, Green Chem., 2010, 12, 1225-1236.

24 J. Snyder, T. Fujita, M. W. Chen and J. Erlebacher, Nat. Mater., 2010, 9, 904-907.

25 Y. Tan, C. Xu, G. Chen, N. Zheng and Q. Xie, Energy Environ. Sci., 2012, 5, 6923-6927.

26 J. Snyder, K. Livi and J. Erlebacher, Adv. Funct. Mater., 2013, 23, 5494-5501.

27 C. Chen, Y. Kang, Z. Huo, Z. Zhu, W. Huang, H. L. Xin, J. D. Snyder, D. Li, J. A. Herron, M. Mavrikakis, M. Chi, K. L. More, Y. Li, N. M. Markovic, G. A. Somorjai, P. Yang and V. R. Stamenkovic, Science, 2014, 343, 1339-1343.

28 E. Benn, H. Uvegi and J. Erlebacher, J. Electrochem. Soc., 2015, 162, H759-H766.

29 G.-R. Zhang and B. J. Etzold, J. Energy Chem., 2016, 25, 199207.

30 H. A. Gasteiger, S. S. Kocha, B. Sompalli and F. T. Wagner, Appl. Catal., B, 2005, 56, 9-35.

31 W. Xu, J. Xiao, D. Wang, J. Zhang and J.-G. Zhang, J. Electrochem. Soc., 2010, 157, A219-A224.

$32 \mathrm{~W}$. Xu, J. Xiao, J. Zhang, D. Wang and J.-G. Zhang, J. Electrochem. Soc., 2009, 156, A773-A779.

33 S. A. Freunberger, Y. Chen, N. E. Drewett, L. J. Hardwick, F. Bardé and P. G. Bruce, Angew. Chem., Int. Ed., 2011, 50, 8609-8613.

34 F. Mizuno, S. Nakanishi, A. Shirasawa, K. Takechi, T. Shiga, H. Nishikoori and H. Iba, Electrochemistry, 2011, 79, 876881.

35 C. O. Laoire, S. Mukerjee, E. J. Plichta, M. A. Hendrickson and K. M. Abraham, J. Electrochem. Soc., 2011, 158, A302A308.

36 J. Herranz, A. Garsuch and H. A. Gasteiger, J. Phys. Chem. C, 2012, 116, 19084-19094.

37 B. M. Gallant, D. G. Kwabi, R. R. Mitchell, J. Zhou, C. V. Thompson and Y. Shao-Horn, Energy Environ. Sci., 2013, 6, 2518-2528. 
38 C. O. Laoire, S. Mukerjee, K. M. Abraham, E. J. Plichta and M. A. Hendrickson, J. Phys. Chem. C, 2009, 113, 20127-20134.

39 Z. Peng, S. A. Freunberger, L. J. Hardwick, Y. Chen, V. Giordani, F. Bardé, P. Novák, D. Graham, J.-M. Tarascon and P. G. Bruce, Angew. Chem., 2011, 123, 6475-6479.

40 F. Bardé, Y. Chen, L. Johnson, S. Schaltin, J. Fransaer and P. G. Bruce, J. Phys. Chem. C, 2014, 118, 18892-18898.

41 K. U. Schwenke, S. Meini, X. Wu, H. A. Gasteiger and M. Piana, Phys. Chem. Chem. Phys., 2013, 15, 11830-11839.

42 A. C. Luntz and B. D. McCloskey, Nat. Energy, 2017, 2, 17056.

43 C. J. Allen, J. Hwang, R. Kautz, S. Mukerjee, E. J. Plichta, M. A. Hendrickson and K. M. Abraham, J. Phys. Chem. C, 2012, 116, 20755-20764.

44 G. Girishkumar, B. McCloskey, A. C. Luntz, S. Swanson and W. Wilcke, J. Phys. Chem. Lett., 2010, 1, 2193-2203.

45 T. Ogasawara, A. Débart, M. Holzapfel, P. Novák and P. G. Bruce, J. Am. Chem. Soc., 2006, 128, 1390-1393.

46 J. G. Riess, Colloids Surf., A, 1994, 84, 33-48.

47 J. G. Riess, Chem. Rev., 2001, 101, 2797-2920.

48 A. M. A. Dias, R. P. Bonifacio, I. M. Marrucho, A. A. H. Padua and M. F. C. Gomes, Phys. Chem. Chem. Phys., 2003, 5, 543549.

49 M. F. C. Gomes, J. Deschamps and D. H. Mertz, J. Fluorine Chem., 2004, 125, 1325-1329.

50 Fluorine and Health: Molecular Imaging, Biomedical Materials and Pharmaceuticals, ed. M. P. Krafft and J. G. Riess, Elsevier, Amsterdam, 2008.

51 R. Yazami, US Pat. 0266907 A1, October 21, 2010.

52 M. Balaish, A. Kraytsberg and Y. Ein-Eli, Phys. Chem. Chem. Phys., 2014, 16, 2801-2822.

53 M. Balaish, A. Kraytsberg and Y. Ein-Eli, ChemElectroChem, 2014, 1, 90-94.

54 Y. Wang, D. Zheng, X.-Q. Yang and D. Qu, Energy Environ. Sci., 2011, 4, 3697-3702.
55 Y. Nishikami, T. Konishi, R. Omoda, Y. Aihara, K. Oyaizu and H. Nishide, J. Mater. Chem. A, 2015, 3, 10845-10850.

56 T. L. Merrigan, E. D. Bates, S. C. Dorman and J. H. Davis, Chem. Commun., 2000, 2051-2052.

57 J. E. Bara, T. K. Carlisle, C. J. Gabriel, D. Camper, A. Finotello, D. L. Gin and R. D. Noble, Ind. Eng. Chem. Res., 2009, 48, 2739-2751.

58 D. Almantariotis, T. Gefflaut, A. A. H. Padua, J. Y. Coxam and M. F. C. Gomes, J. Phys. Chem. B, 2010, 114, 3608-3617.

59 T. Alpers, M. Schmidtmann, T. W. T. Muesmann, O. Temme and J. Christoffers, Eur. J. Org. Chem., 2017, 4283-4290.

60 D. Rauber, P. Zhang, V. Huch, T. Kraus and H. Rolf, Phys. Chem. Chem. Phys., 2017, 19, 27251-27258.

61 D. Rauber, F. Heib, M. Schmitt and R. Hempelmann, Colloids Surf., A, 2018, 537, 116-125.

62 A. B. Pereiro, J. a. M. M. Araujo, S. Martinho, F. Alves, S. Nunes, A. Matias, C. M. M. Duarte, L. P. N. Rebelo and I. M. Marrucho, ACS Sustainable Chem. Eng., 2013, 1, 427439.

63 D. Almantariotis, A. S. Pensado, H. Q. N. Gunaratne, C. Hardacre, A. A. H. Padua, J. Y. Coxam and M. F. C. Gomes, J. Phys. Chem. B, 2017, 121, 426-436.

64 A. B. Pereiro, F. Llovell, J. a. M. M. Araujo, A. S. S. Santos, L. P. N. Rebelo, M. M. Pineiro and L. F. Vega, ChemPhysChem, 2017, 18, 2012-2023.

65 D. Rauber, F. Heib, T. Dier, D. A. Volmer, R. Hempelmann and M. Schmitt, Colloids Surf., A, 2017, 529, 169-177.

66 J. Kim, R. P. Singh and J. M. Shreeve, Inorg. Chem., 2004, 43, 2960-2966.

67 H. Nakamoto, Y. Suzuki, T. Shiotsuki, F. Mizuno, S. Higashi, K. Takechi, T. Asaoka, H. Nishikoori and H. Iba, J. Power Sources, 2013, 243, 19-23. 